\title{
Nurturing academic writing for students in an enrolled to registered nurse conversion course at university
}

\author{
Elizabeth N.M. Emmanuel*1, Marilyn Chaseling², Bill Boyd ${ }^{3}$ \\ ${ }^{1}$ School of Health and Human Sciences, Gold Coast, Southern Cross University, Queensland, Australia \\ ${ }^{2}$ School of Education, Southern Cross University, Lismore, NSW, Australia \\ ${ }^{3}$ School of Environmental, Science and Engineering, Southern Cross University, Lismore, NSW, Australia
}

Received: March 2, 2019

Accepted: April 28, 2019

Online Published: May 24, 2019

DOI: $10.5430 /$ jnep.v9n8p121

URL: https://doi.org/10.5430/jnep.v9n8p121

\begin{abstract}
A growing number of diploma-qualified nurses from vocational programs are enrolling in university Bachelor of Nursing programs to upgrade their qualifications. Universities typically provide these students with credit so they enter the Bachelor of Nursing program in second year. Known as pathway students, these students tend to miss the orientating opportunities that other students experience in their first-year university enrolment. This lack of first-year opportunity can be challenging for many pathway students, notably in academic writing. This paper reports on a tailored and scaffolded academic-writing teaching strategy designed for pathway students in their initial semester of learning. Both the students themselves, and teachers report evidence of improvements in academic writing amongst the pathway students.
\end{abstract}

Key Words: Pathway student, Nursing student, Academic writing, Scaffolded learning

\section{INTRODUCTION}

\section{Challenges for pathway students}

In various Western countries, including Australia, there are a growing number of diploma-qualified nurses from vocational programs enrolling in university Bachelor of Nursing programs to upgrade their qualifications. ${ }^{[1-3]}$ Universities typically provide these students, known as pathway students, with credit (advanced standing or recognition of prior learning), and so they enter their Bachelor of Nursing program in second year. Students without a prior nursing qualification, in contrast, commence their program in first year. A significant difference between these two cohorts of students, other than the prior professional experience they bring, is that the latter group is more strongly nurtured into university through first year studies tailored, in part, to initiate students into the academic skills required for successful university learning. Pathway students, on the other hand, miss this nurturing stage. It is this significant gap in student learning that this article addresses.

In Australia, the sector of education, within the tertiary education system, that provides pre-degree qualifications (e.g. prepares diploma-qualified nurses) is known as Vocational Education and Training (VET), and takes place in government institutions, called TAFEs (Technical and Further Education institutions), as well as in private institutions (Australian Government, no date). Vocational programs focus on specialised knowledge and skills, training and competencies, ${ }^{[4]}$ which make a person employable, or more employable, in an occupation or family of occupations. ${ }^{[5]}$ Advantages of such courses include lower admission requirements, lower

\footnotetext{
*Correspondence: Elizabeth N.M. Emmanuel; Email: elizabeth.emmanuel@ scu.edu.au; Address: School of Health and Human Sciences, Gold Coast, Southern Cross University, Queensland, Australia.
} 
program costs than for university, easier access, and opportunities to study close to home. The direct link between the world of practical work and what is taught in a vocational curriculum means that students are usually interested and motivated to learn the skills they need. ${ }^{[5]}$ These skills are usually taught in classes with a small student-teacher ratio, for which students are routinely supported, guided and assisted in their learning by their teachers. ${ }^{[6]}$

Learning at university is different to learning in other sectors. University learning requires nursing students to develop a broad knowledge base and skills for professional work, with emphasis on higher-order thinking, critical analysis and evidence. ${ }^{[7]}$ It also relies on students being self-motivated and independent learners. ${ }^{[8]}$ In addition, what can be overlooked with university studies, is that the experience itself can be disorienting and transformational as students are required to engage with thought-provoking ideas ${ }^{[9]}$ as they try to reposition themselves in their new learning environment. Pathway students must adjust swiftly to the change of orientation in university. Often, the assumption is that these students will automatically adjust to the demands of second year, even though they are, in reality, in their first year of university study. ${ }^{[1]}$ Evidence indicates that the main challenge for many pathway students during this period of transition into higher education is with academic writing. ${ }^{[7,10]}$ Equivalent challenges have long been experienced by professional people transitioning from employment in industry into employment in universities e.g. Williams, ${ }^{[11]}$ Wilson et al. ${ }^{[12]}$; academics have long sought processes to resolve and mediate these challenges. This paper reports one such approach to supporting students who are transitioning from enrolled nurse status to registered nurse status through enrolment in a university bachelor's degree, and who require to develop academic writing skills in a relatively short period at the start of their studies.

\section{BACKGROUND}

\subsection{The importance of academic writing}

At a professional level, effective writing skills are essential for nursing practice as they enable nurses to communicate patient information and engage in academic discourse. Written communication is important and essential to patient care, as nurses work together in teams with other health professionals. To be effective, student nurses need to write clearly, accurately and coherently ${ }^{[13]}$ because a prime responsibility of their role is to share information and demonstrate their understanding of content specific to the nursing discipline. ${ }^{[14]}$ While courses may assist in developing professional writing, the commencing student's primary issue is to develop a different form of writing, academic writing. It is interesting to note that, at postgraduate level, nursing students felt a lack of fit between the demands of academic writing and the actual practice in nursing. ${ }^{[15]}$ These students reported that academic writing was time consuming and took the focus away from what they felt they needed to learn.

Nevertheless, academic writing is critical to successful completion of studies. Through their written assessments, student nurses need to demonstrate their understanding of safety, high-quality communications, best practice and cost efficiency in the workplace. ${ }^{[16,17]}$ In addition, they need to be able to discuss practice and research and, therefore, communicate ideas from the nursing literature. Learning to write, however, requires practice. Students who have effective academic writing skills are more likely to progress and succeed through their program. ${ }^{[8]}$ Effective academic writing also enhances students' learning experience, academic grades, confidence and can influence their self-efficacy as learners.

At the beginning of their university studies, students' writing skills are generally basic, but can usually improve with the help of various strategies offered by university support services, ${ }^{[14]}$ especially for those students who avail themselves of these opportunities. These services, however, focus mostly on direct-entry students, ${ }^{[8]}$ with little consideration given to the specific learning needs of pathway students. ${ }^{[1]}$

Academic writing can be challenging for many undergraduate students, regardless of the route through which they gain entry to university. Challenges include deconstructing and reconstructing assessment tasks, research skills and application of information across varying contexts, sentence construction and mastery of academic writing conventions. ${ }^{[10]}$ In nursing programs, in particular, practice for developing writing is limited. ${ }^{[14]}$ The different types of written assignments such as essays, concept maps, reports, short papers and journaling encourage learning of the content but do not generally focus on improving writing skills. Foxwell ${ }^{[13]}$ reported that many students were unsure how to compose written work, and that at least $85 \%$ of students lacked confidence in their ability to compose an academic essay. Wingate ${ }^{[18]}$ reported that students struggled with making an argument in essays largely because they did not understand what an argument meant in an essay or how to develop their own stance in the discourse.

\subsection{Strategies and programs for improving academic writing}

In nursing education, a wide range of programs and strategies are available to help students develop their writing skills. In a systematic review of 80 nursing articles, Oermann et al. ${ }^{[14]}$ reported on these which included embedding writing in the curriculum, writing courses, stand-alone workshops, assign- 
ment writing, self-activated activities, and staff responses to student writing through feedback. Of these, the most common means to improve writing skills is the actual practice of writing assignments. Students reported that revisions of drafts by tutors (formative feedback), and spending time at a writing centre with tutors, were important strategies that improved their writing. Despite the variety of strategies and programs, Oermann et al. ${ }^{[14]}$ pointed out that there is no clear indication which of these strategies are most effective.

Various researchers have identified strategies that can improve students' academic writing. According to British nursing academics, Gopee and Deane, ${ }^{[19]}$ healthcare students identified intrinsic and extrinsic factors that motivated students' academic writing. However, factors that hindered academic writing included being unsure about academic writing conventions, lack of confidence in writing, limited tutor support, and absence of support networks. Facilitating academic writing skills required clarity in the structure of the assignment, feedback from markers and practise in writing.

\subsection{Good practice for first year success}

Good practice requires that support is provided to all first years, not just those who seek it out. ${ }^{[20]}$ Support is particularly important for students who may be disadvantaged due to educational, cultural or financial reasons or for those who belong to specific groups that are under-represented in education. Various studies appear in the literature on this issue. For example, Nelson, Quinn ${ }^{[21]}$ report on an intervention targeting students at risk of disengaging with their learning. This involved creating connections for these at-risk students between their personal experiences in the classroom, the program of study and support services. The findings of this study showed positive retention, reflective of good practice, when attention was applied to the various learning contexts that students experienced. A study by Palmer et al. ${ }^{[22]}$ determined first-year nursing students' academic writing skills at the commencement of their unit of study. It found that these students struggled with self-regulating, management and problem-solving skills. Appropriate support and early feedback provided these students with the needed opportunity and guidance to achieve success. As a result, approximately $77 \%$ of these students improved, which led to these students achieving a pass or higher grade.

\subsection{Strategies for specific groups}

Specific groups of university students have different learning needs. For example, Gopee and Deane ${ }^{[19]}$ reported that international students have difficulty with academic writing particularly if there is no provision for academic-writing resources. Pinetah ${ }^{[10]}$ pointed out that students of differ- ent races, socio-economic status, linguistic background and ways of thinking are disadvantaged when immersed in the dominant discourse that takes place in the university setting.

Another disadvantaged group are pathway students. O'Shea et al. ${ }^{[1]}$ identified these students as non-visible amidst the main cohort of direct-entry first years. These pathway students experience the same gamut of challenges attributed to first years but, by beginning their university studies in second year, they have less time to make adjustments and become familiar with the theoretical and inquiry-based environment of university. This can add to their sense of isolation and uncertainty. The learning needs of pathway students needs addressing.

This study, therefore, seeks to fill a gap in the literature in terms of an approach to support pathway students to develop their academic writing skills in their first semester at university. The study addresses the question of what is an effective academic writing strategy to support pathway students. The strategy arose from the first author's experiences of teaching pathway students at which time she identified their specific needs and hurdles.

\section{THE STUDY SETTING}

\subsection{The pathway students}

The setting for this study was a regional university in Australia whose three campuses are spread across two states. The university's nursing-related undergraduate teaching program comprises a three-year Bachelor of Nursing, and a two-year Bachelor of Nursing Enrolled Nurse to Registered Nurse Pathway. As discussed earlier, these pathway students commence their university study as a second-year student, even though they are in their first year of university (see Table 1). In their second and hence final year, pathway students join with Direct-Entry Bachelor of Nursing students. These two cohorts complete their third, and hence final year together. Therefore, both cohorts complete their final year together.

In the first session of their university studies, pathway students enrol in four courses/units. This includes a foundation nursing course/unit that comprises a one-week on-campus residential, which is followed by eleven weeks of online learning study (see Table 2). As part of this course/unit, students also complete a two-week (80-hours) work placement in a hospital. It is this foundation unit that is the subject of this study.

\subsection{Foundation course/unit}

The aims of this foundation nursing unit are to: analyse the meaning of nursing care in relation to multiple narratives of health and illness; analyse the impact of current trends in the 
health care system; discuss the statutory and professional requirements that regulate nursing practice; demonstrate an understanding of academic integrity and writing, and; describe the development of knowledge that informs and constructs conceptual-based thinking. Students are expected to read and critically analyse the evidence from the literature on a range of topics, and consider how this may be integrated into their submitted assignments.

Table 1. The bachelor of nursing program for pathway and direct-entry students

\begin{tabular}{|c|c|c|c|c|c|c|}
\hline & \multicolumn{6}{|l|}{ Bachelor of Nursing } \\
\hline & \multirow[t]{3}{*}{ Pathway students } & \multicolumn{5}{|c|}{ Direct-entry students } \\
\hline & & \multicolumn{2}{|c|}{ Units/semester } & & \multicolumn{2}{|c|}{ Units/semester } \\
\hline & & Semester 1 & Semester 2 & & Semester 1 & Semester 2 \\
\hline Year 1 & $\begin{array}{l}\text { Not required ( } 8 \text { units of credit } \\
\text { granted on the basis of } \\
\text { completed vocational program) }\end{array}$ & 0 & 0 & $\begin{array}{l}\text { Enrol in first year of } \\
\text { university study }\end{array}$ & 4 & 4 \\
\hline Year 2 & $\begin{array}{l}\text { Enrol in first year of university } \\
\text { study }\end{array}$ & 4 & 4 & $\begin{array}{l}\text { Enrol in second year } \\
\text { of university study }\end{array}$ & 4 & 4 \\
\hline Year 3 & $\begin{array}{l}\text { Enrol in second year of } \\
\text { university study }\end{array}$ & 4 & 4 & $\begin{array}{l}\text { Enrol in third year of } \\
\text { university study }\end{array}$ & 4 & 4 \\
\hline Total Units & & \multicolumn{2}{|c|}{$\begin{array}{l}24 \text { (16 units of study }+8 \\
\text { units of credit) }\end{array}$} & & \multicolumn{2}{|c|}{24 (24 units of study) } \\
\hline
\end{tabular}

Table 2. Foundation Unit, one of four, which commencing pathway students undertake in their first semester

\begin{tabular}{|c|c|c|c|c|c|}
\hline \multirow{3}{*}{ Week } & \multicolumn{5}{|c|}{ Foundations Nursing Unit for Pathway Students } \\
\hline & \multirow{2}{*}{ Unit Delivery } & \multicolumn{3}{|c|}{ Written Assessment } & \multirow{2}{*}{$\begin{array}{l}\text { Clinical } \\
\text { Placement }\end{array}$} \\
\hline & & Assessment Type & Weighting & Objective & \\
\hline 1 & 5-day Residential & & & & \\
\hline \multicolumn{6}{|l|}{$2-5$} \\
\hline 6 & Online coursework & $\begin{array}{l}\text { Annotated } \\
\text { Bibliography } \\
\text { (1,500 words) }\end{array}$ & $50 \%$ & $\begin{array}{l}\text { Integrate understanding of content } \\
\text { knowledge, structure, critical thinking, } \\
\text { paragraphing, referencing }\end{array}$ & \\
\hline $7-11$ & \multicolumn{5}{|l|}{ Study Week } \\
\hline \multicolumn{6}{|l|}{$8-11$} \\
\hline 12 & \multirow[t]{2}{*}{ Online coursework } & $\begin{array}{l}\text { Essay } \\
\text { (1,500 words) }\end{array}$ & $50 \%$ & $\begin{array}{l}\text { Integrate feedback on academic writing } \\
\text { Demonstrate a better understanding of } \\
\text { assignment writing }\end{array}$ & \\
\hline \multicolumn{5}{|l|}{13} & \\
\hline $\begin{array}{l}\text { Semester } \\
\text { Break }\end{array}$ & & & & & $\begin{array}{l}2 \text { week- } \\
\text { placement in a } \\
\text { hospital }\end{array}$ \\
\hline
\end{tabular}

\subsection{Assignments}

This course/unit has two written 1,500-word assessment items, both worth $50 \%$ (see Table 2). The first is an annotated bibliography on one of three topics: patients' rights in health care; scope of practice; or health outcomes in Indigenous health. In this assignment, students choose three articles and provide a short description or summary of the content, a brief critical analysis, and an evaluation of the article's relevance to nursing practice. The second assignment is an essay on the changing national population profile and its impact on the health-care system, the challenges that arise or may arise, and implications for nurses. Here, students examine different sources of relevant information, address the different components of the essay question, and integrate the feedback they received from their first assignment.

\section{THE ACADEMIC WRITING PROJECT}

\subsection{A six-pronged strategy to develop commencing stu- dents academic writing}

A six-pronged strategy was undertaken to support students' academic writing development (see Table 3). The first strategy was the decisions made on the nature of the two assess- 
ment tasks, that the first assignment would require students to engage in a very basic academic research and writing activity (a library catalogue search to locate three articles, and a brief written summary and critical analysis of these) and that, only after students had received extensive written, formative feedback on their writing, would they progress to the more complex activity of writing an essay. As detailed in Table 3 and explained in more detail below, the second strategy was to provide students, during their first week of university (an on-campus intensive), with daily carefully scaffolded support for their two assignments by staff external to the unit (a university librarian and an academic skills advisor). ${ }^{[23]}$ The third strategy was to extend this support during onehour weekly optional Blackboard Collaborate sessions. As a fourth strategy, two mp4 video presentations were prepared, each with clear, prescriptive instructions for both assessment tasks. ${ }^{[24]}$ The decision that tutors would provide students with prompt and extensive written feedback on their first written task (assignment 1 ) - formative feedback ${ }^{[25]}$ through Microsoft Word's Track Changes and Comments functions was the fifth strategy. Comments involved questions, suggestions, links to resources, and examples for improved writing. Through this feedback, students were encouraged to become more aware of the need to read and engage with the unit content and to write more effectively. Negretti ${ }^{[26]}$ refers to this as developing metacognitive awareness, described as the "ability to know when and how knowledge and strategies should be applied" (p. 44). The sixth, and final, strategy was that the same tutor would mark both assignments. This allowed for follow-up on feedback given on Assignment 1 and students to be given feedback on improvements they had made in their Assignment 2.

Table 3. Scaffolded support for assessment task during residential intensive week and during the semester

\begin{tabular}{|c|c|c|c|}
\hline Time & Activity & Time & Objective \\
\hline Day 1 & $\begin{array}{l}\text { How to unpack and structure } \\
\text { an annotated bibliography }\end{array}$ & 30 mins & $\begin{array}{l}\text { Develop skills to unpack the assignment } \\
\text { What is an annotated bibliography? } \\
\text { What is being asked in the assignment? } \\
\text { Academic writing conversions (e.g. sentences and paragraphs; } \\
\text { correct punctuation, spelling and grammar) }\end{array}$ \\
\hline Day 2 & Critical thinking & 30 mins & What does it mean to think critically in a university context? \\
\hline Day 3 & How to write a paragraph & 30 mins & $\begin{array}{l}\text { Provide students with a framework to help them structure their } \\
\text { paragraph- PEES framework (Point of argument, Explaining, } \\
\text { Elaborating and Summarising structure) } \\
\text { Discuss sample paragraphs and their structure } \\
\text { How/where is critical thinking embedded in the sample paragraphs? }\end{array}$ \\
\hline Day 4 & $\begin{array}{l}\text { How to use APA } 6^{\text {th }} \text { Edition } \\
\text { Referencing format }\end{array}$ & 30 mins & $\begin{array}{l}\text { Why reference? } \\
\text { Using in-text references and a References list } \\
\text { How to reference a journal article? }\end{array}$ \\
\hline Day 5 & $\begin{array}{l}\text { Write an academic paragraph } \\
\text { and receive feedback }\end{array}$ & 60 mins & $\begin{array}{l}\text { Write a paragraph using the PEES structure } \\
\text { Receive and provide feedback on the paragraph from/ to a peer }\end{array}$ \\
\hline Week 2-12 & Weekly (online) tutorials & 60 mins & $\begin{array}{l}\text { Discuss weekly course/unit content } \\
\text { Discuss assignment questions }\end{array}$ \\
\hline Week 2 & mp4 video & 10 mins & $\begin{array}{l}\text { Annotated Bibliography PowerPoint presentation containing slides } \\
\text { on how to answer the assignment question; researching the topic; } \\
\text { organise ideas; drafting the assignment }\end{array}$ \\
\hline Week 7 & mp4 video & 10 mins & $\begin{array}{l}\text { Essay presentation PowerPoint presentation building on the first } \\
\text { assignment and integrating feedback provided by the marker }\end{array}$ \\
\hline
\end{tabular}

During the intensive week mentioned above, a university librarian and an academic skills advisor offered support to students. As the first assignment was an annotated bibliography, the librarian provided two sessions on literature searching and on the practicalities of databases. During these sessions, students were introduced to exploring a topic, narrowing their search, and teasing out how to obtain current and peer-reviewed journal articles. They were also, reminded that they could use the articles they found during these two library sessions, for their first assignment. The academic skills advisor provided daily segments on academic writing. The overall outcome and grade distribution of the two assignments is shown in Table 4.

While student feedback on university-administered anonymous surveys is routinely low ${ }^{[27]}$ formal feedback at the end 
of the teaching session, using the University's anonymous student evaluation of the course/unit of study, indicated the effectiveness of the writing strategy (see Table 5). Twentynine of the 99 students in the class submitted feedback on teaching. Students had a higher level of satisfaction in 2017, when the strategy was introduced, compared to the previous year.

Table 4. Grade distributions for the two assignments in the foundation unit

\begin{tabular}{lllllll}
\hline & $\begin{array}{l}\text { Fail } \\
(<\mathbf{5 0} \%)\end{array}$ & $\begin{array}{l}\text { Pass } \\
\mathbf{( 5 0 \% - 6 4 \% )}\end{array}$ & $\begin{array}{l}\text { Credit } \\
\mathbf{( 6 5 \% - 7 4 \% )}\end{array}$ & $\begin{array}{l}\text { Distinction } \\
\mathbf{( 7 5 \% - 8 4 \% )}\end{array}$ & $\begin{array}{l}\text { High Distinction } \\
\mathbf{( 8 5 \% - 1 0 0 \% )}\end{array}$ & No show \\
\hline Assignment 1 (63 students) & 4 & 27 & 14 & 11 & 3 & 4 \\
Assignment 2 (59 students) & 3 & 29 & 13 & 6 & 2 & 6 \\
\hline
\end{tabular}

Table 5. Summary of the formal university teaching evaluation and student feedback, based on feedback from those students who chose to complete the survey ( 29 of the 99 students), where students are asked to record their responses on a five-point scale of 1 (low satisfaction) to 5 (high satisfaction)

\begin{tabular}{lll}
\hline & $\mathbf{2 0 1 6}$ & $\mathbf{2 0 1 7}$ \\
\hline I am satisfied with the assessment tasks in this unit & $3.00 / 5$ & $3.95 / 5$ \\
The unit helped me to develop some valuable skills/attributes & $3.90 / 5$ & $4.05 / 5$ \\
Overall, I am satisfied with this unit & $3.50 / 5$ & $4.05 / 5$ \\
\hline
\end{tabular}

Qualitative student feedback highlighted three important themes of satisfaction, that the unit:

- recognised the needs of this specific (pathways) cohort.

- used a how-to approach for academic writing.

- made sense to students of what is meant by critical thinking and embedded in academic writing.

Students expressed their satisfaction with their personal achievement in the unit. One wrote, "I cannot believe that this is my work. I always thought I was hopeless at writing". Another student reflected, "I always knew I could write well but never at university standard. This has opened my mind to all kinds of possibilities". Another stated, "Now I have a better idea about structuring an essay. I don't need to waste time worrying about what you expect in my written work".

It is not, however, only the students who noticed and reported improvements in their academic writing. The unit assessor for a unit during the following semester later observed that the students' writing in this cohort was notably improved over previous years. Furthermore, this cohort of students was notable by being the first to attract no comments from their final year lecturers regarding weak academic writing, especially in final session report writing.

\subsection{Evaluating the academic writing program}

This study adopted a step-by-step approach to academic writing for pathway students within a foundational nursing unit. It is difficult to demonstrate measurable learning outcome changes for such a program, especially since there are many variables that influence change in a student's potential success. It is possible, however, to evaluate the uptake of pre-cursors to behavioural change; ${ }^{[28]}$ see also the crucial role of pre-cursors to behaviour change in Ajzen's ${ }^{[29]}$ Theory of Planned Behaviour. In an educational setting, such pre-cursors would notably include indicators of students' enhanced appreciation of the skills and behaviours required for successful academic writing. In this study, we evaluate these through our own and our students' reflection of that appreciation. The reflective mode in educational research is important, powerful and widely used, and hence we consider it an appropriate method to adopt in this study. ${ }^{[30,31]}$ Evaluation of data indicates that the approach allowed for students to gain a better understanding as to the depth of knowledge needed at tertiary level, and what academic writing entailed. Students developed an appreciation of the adopted convention of writing, which involves clarity, conciseness, structure, and use of evidence. More importantly, the approach encouraged students to develop academic writing skills essential for academic success and progression. As identified in recent literature, ${ }^{[1,7,10]}$ these skills are key to student engagement in the first year of tertiary studies. For pathway students, in particular, a tailored and scaffolded approach provided an effective learning strategy for improvement in their academic writing skills. The foundational unit, for students coming from a vocational background where the emphasis is on training and competency, seemed an appropriate place to focus on the basics of academic writing. The positive results affirm McWilliams et al.' $\mathrm{s}^{[32]}$ emphasis for university programs to respond to students' needs and accommodate their learning 
to what is known about specific cohorts.

Despite the positive results, there were limitations. Around $16 \%$ (10 students) of the cohort did drop out, despite passing their two submitted assignments; they could not continue their studies due to lifestyle commitments and responsibilities. While a third of the students improved in their second assignment, at least one third of students' scores were lower when compared to their first assignment. A different approach, format, and level of critical reasoning required in the second assignment, an essay, may explain the lower scores. Importantly, however, when compared to the previous year's cohort, tutors who did the marking reported there was an overall improvement.

This study demonstrates a positive impact on the academic writing skills for pathway students who are enrolled as pathway students. The program organisation, combined with a structured or scaffolded approach to developing academic writing skills, enabled the students to build incrementally on their skills and knowledge already acquired from their previous diploma study. O'Shae et al. ${ }^{[1]}$ report on the differences between vocational education and higher education that influences teaching styles and expectations of students' performance in assignments. Awareness of such differences by university academic staff assists in the planning for preparing pathway students as they make the transition to tertiary studies. In this present study, the academic writing approach not only eased the students' transition into tertiary studies, but validated their capacity for higher studies, thus giving them confidence and encouragement.

\section{Conclusions}

Transitioning into tertiary studies can be challenging for pathway nursing students. Academic writing adds to this challenge. One way to facilitate the transition is to embed academic writing skills within the curriculum. A collaborative approach, combined with the expertise of other specialists (academic skills and librarians), can smooth the transition whereby students can experience success early in their university career. The academic writing strategy presented here illustrates how nurse educators can increase awareness about academic writing, and can facilitate student skill development. Development of academic writing skills can take time, and success may be difficult to demonstrate in the shortterm. Nevertheless, the positive reception of this approach by the cohort of students engaged here suggests that positive scholarly outcomes will emerge for this group of students. Effective academic writing has the potential to enhance the experience of tertiary studies, increase academic success, and reduce attrition. A tailored approach to meet the needs of pathway students, recognising the students' prior experience and the program context which they are joining, shows that the university-wide mainstream approach of one size fits all may not be the best way to support specific groups.

\section{CONFLICTS OF INTEREST DISCLOSURE}

The authors declare that there is no conflict of interest statement.

\section{REFERENCES}

[1] O'Shea S, Lysaght P, Tanner K. Stepping into higher eduation from the vocational education sectio in Australia: student perceptions and experiences. Journal of Vocational Education and Training. 2012; 64(3): 261-77. https://doi.org/10.1080/13636820.2 012.691532

[2] Potter A, Bye L. It might have worked for you but ... Evaluating the efficacy of a first year support strategy in multiple units and disciplines. The International Journal of the First Year in Higher Education. 2014; 5(2): 57-68. https://doi.org/10.5204/intj fyhe.v5i2.232

[3] Komulainen P, Tani P, Ylikoski T, et al. Facilitating the trasnition to higher education with a digital pathway. International Conference of Education, Research and Innovation Proceedings. 2017; Spain. https://doi.org/10.21125/iceri.2017.0196

[4] Heusdens W, Baartman L, De Bruijn E. Knowing everything from soup to dessert: an exploratory study to describe what characterises students' vocational knowledge. Journal of Vocational Education \& Training. 2018; 70 (3): 435-54. https ://doi.org/10.1080/13 636820.2018 .1437065

[5] Akinwumiju J. An analysis of basic academic skills associated with success in various areas of vocational education: A technique for planning academic programs. 2010.

[6] Norton Grubb W. Vocationalism and the differentiation of tertiary education: lessons from US community colleges. Journal of Further and Higher Education. 2006; 30(1): 27-42. https : //doi .org/10 $.1080 / 03098770500431973$

[7] Price B. Applying critical thinking to nursing. Nursing Standard. 2015; 29(51): 40-58. PMid:26103872 https://doi.org/10.774 $8 / \mathrm{ns} \cdot 29 \cdot 43 \cdot 51 . \mathrm{e} 9654$

[8] Thies L, Wallis A, Turner A, et al. Embedded academic literacies curricula: the challenges of measuring success. Journal of Academic Language and Learning. 2014; 8(2): A43-A59.

[9] Mezirow J. Perspective Transformation. Studies in Adult Education. 1977; 9(2): 153-64. https://doi.org/10.1080/02660830.197 7.11730750

[10] Pineteh A. The Academic Writing Challenges of Undergraduate Students: A South African Case Study. International Journal of Higher Education. 2014; 3(1): 12-22. https://doi.org/10.5430/ijhe .v3n1p12

[11] Williams J. Constructing a new professional identity: Career change into teaching. Teaching and Teacher Education. 2010; 26(3): 639-47. https://doi.org/10.1016/j.tate.2009.09.016 
[12] Wilson M, Wood L, Solomonides I, et al. Navigating the career transition from industry to academia. Industry \& Higher Education. 2014; 28(1): 5-13. https://doi.org/10.5367/ihe.2014.0189

[13] Foxwell E. Academic writing. Nursing Standard. 2008; 22(41): 59. https://doi.org/10.7748/ns.22.41.59.s44

[14] Oermann MH, Leonardelli AK, Turner KM, et al. Systematic review of educational programs and strategies for developing students' and nurses' writing skills. The Journal of Nursing Education. 2015; 54(1): 28-34. PMid:25535756 https : //doi .org/10.3928/0148 4834-20141224-01

[15] Johansen E, Harding T. 'So I forgot to use 1.5 line spacing! it doesn't make me a bad nurse!' the attitudes to and experiences of a group of norwegian postgraduate nurses to academic writing. Nurse Education in Practice. 2013; 13(5): 366-70. PMid:23137938 https://doi.org/10.1016/j.nepr.2012.10.001

[16] Ledade S, Jain S, Darji A, et al. Narrative writing: effective ways and best practices. Perspectives in Clinical Research. 2017; 8(2): 58-62. PMid:28447014 https ://doi.org/10.4103/2229-3485.2030 44

[17] Hanson Diehl S. Developing students'writing skills: an early intervention approach. Nurse Educator. 2007; 32(5): 202-6. PMid:17828020 https://doi.org/10.1097/01. NNE.0000289377.06384.00

[18] Wingate U. 'Argument!' helping students understand what essay writing is about. Journal of English for Academic Purposes. 2012; 11(2): 145-54. https://doi .org/10.1016/j.jeap.2011.11.001

[19] Gopee N, Deane M. Strategies for successful academic writin: Institutional and non-institutional support for students. Nurse Education Today. 2013; 33(12): 1624-31. PMid:23473750 https: //doi.org/10.1016/j.nedt.2013.02.004

[20] Adams T, Banks M, Davis D, et al. The Hobsons retention project. Melbourne; 2010.

[21] Nelson K, Quinn C, Marrington A, et al. Good practice for enhancing the engagement and success of commencing students. Higher Education Research and Development. 2012; 63(1): 83-96. https : //doi.org/10.1007/s10734-011-9426-y

[22] Palmer L, Levett-Jones T, Smith R, et al. Academic literacy diagnostic assessment in the first semester of first year at university. The
International Journal of the First Year in Higher Education. 2014; 5(1): 67-78. https://doi.org/10.5204/int jfyhe.v5i1. 201

[23] Jackson D. Mentored residential writing retreats: a leadership strategy to develop skills and generate outcomes in writing for publication. Nurse Education Today. 2009; 29(1): 9-15. PMid:18692282 https : //doi.org/10.1016/j.nedt.2008.05.018

[24] McDonald PL, Harwood KJ, Butler JT, et al. Design for success: Identifying a process for transitioning to an intensive online course delivery model in health professions education. Medical Education Online. 2018; 23(1): 1415617. PMid:29277143 https://doi .org/10.1080/10872981.2017.1415617

[25] Hardavella G, Aamli-Gaagnat A, Saad N, et al. How to give and receive feedback effectively. Breathe (Sheffield, England). 2017; 13(4): 327-33. PMid:29209427 https://doi .org/10.1183/20734735 .009917

[26] Negretti R. Metacognition in Student Academic Writing:A Longitudinal Study of Metacognitive Awareness and Its Relation to Task Perception, Self-Regulation, and Evaluation of Performance. Written Communication. 2012; 29(2): 142-79. https : //doi.org/10.117 7/0741088312438529

[27] Nair S, Adams P, Mertova P. Student Engagement: The Key to Improving Survey Response Rates. 2008. 225-32 p. https : //doi .or $\mathrm{g} / 10.1080 / 13538320802507505$

[28] Lake W, Boyd WE, Boyd W. Transforming student expectations through a real-time feedback process and the introduction of concepts of self efficacy - surprising results of a university-wide experiment. Journal of University Teaching \& Learning Practice. 2018; 15(5): 23.

[29] Ajzen I. The theory of planned behavior. Organizational Behavior and Human Decision Processes. 1991; 50: 179-211. https: //doi.org/10.1016/0749-5978(91)90020-T

[30] Boyd B. The Literacy Advisor. 2018. Available from: https: //literacyadvisor.wordpress.com/

[31] Boyd B, Grant A. Unveiling opportunities for hope: Is it too much to ask for a compassionate university? Australian Universities Review. 2019; 61(1): 71-5.

[32] McWilliams R, Allan Q. Embedding academic literacy skills: towards a best practice model. Journal of University Teaching \& Learning Practice. 2014; 11(3). 